\title{
A histology-free description of the branched-proboscis ribbonworm Gorgonorhynchus albocinctus sp. nov. (Nemertea: Heteronemertea)
}

\section{AUTHOR(S):}

KAJIHARA, Hiroshi

\section{CITATION:}

KAJIHARA, Hiroshi. A histology-free description of the branched-proboscis ribbonworm Gorgonorhynchus albocinctus sp. nov. (Nemertea: Heteronemertea). Publications of the Seto Marine Biological Laboratory 2015, 43: 92-102

\section{ISSUE DATE:}

2015-09-15

URL:

http://hdl.handle.net/2433/199852

RIGHT: 
Publ. Seto Mar. Biol. Lab., 43: 92-102, 2015

\title{
A histology-free description of the branched-proboscis ribbonworm Gorgonorhynchus albocinctus sp. nov. (Nemertea: Heteronemertea)
}

\author{
HIROSHI KAJIHARA \\ Faculty of Science, Hokkaido University, Sapporo 060-0810, Japan \\ E-mail: kazi@mail.sci.hokudai.ac.jp
}

\begin{abstract}
A new species of heteronemertean with branched proboscis, Gorgonorhynchus albocinctus sp. nov., is described based on the external feature and DNA sequences from a specimen collected subtidally among coral rubbles at a depth of about $6 \mathrm{~m}$ in a reef area around Taketomi Island in the Yaeyama Islands, southwestern Japan. It can be classified in the genus because the mode of proboscis branching is dichotomous, rather than alternating laterally. From the two known congeners G. repens Dakin and Fordham, 1931 and G. bermudensis Wheeler, 1940, the new species can be differentiated by having a brown body colour with a white band near the tip of the head. The new species is placed in a molecular phylogenetic context with a maximum-likelihood analysis using the nuclear 18S rRNA and 28S RNA genes, as well as the mitochondrial cytochrome c oxidase subunit I gene, together with 20 species of heteronemerteans, for which those sequences were available in the public databases. The results indicate that $G$. albocinctus is closely related to Cerebratulus leucopsis (Coe, 1901), a species that is supposed to have a non-branched proboscis.
\end{abstract}

Keywords: Pilidiophora, Gorgonorhynchidae, COI, DNA barcoding, East China Sea, Philippine Sea, marine invertebrates

\section{Introduction}

Six species in five genera of heteronemerteans have been known to possess a branched proboscis, in contrast to the normal, straight, tubular organ found in the rest of the members in the phylum. These are Gorgonorhynchus repens Dakin and Fordham, 1931, G. bermudensis Wheeler, 1940, Panorhynchus argentinensis Serna de Esteban and Moretto, 1969, Polybrachiorhynchus dayi Gibson, 1977, Polydendrorhynchus zhanjiangensis (Yin and Zeng, 1984), and Oligodendrorhynchus hesperides Fernández-Álvarez and Anadón, 2012. The species in Gorgonorhynchus Dakin and Fordham, 1931 are different from others in that the proboscis is dichotomously branched, whereas in others it is comprised of a main stem with alternating lateral branches that can be further forked into tertiary or quaternary branchlets (Gibson, 1977; Sun, 2006; Fernández-Álvarez and Anadón, 2012). The two congeners, G. repens and G. bermudensis, are both distributed in warmer waters, with the former having been reported from eastern Australia (Dakin and Fordham, 1931; Gibson, 1981), Bikini Atoll (Coe, 1947), and India (Graveley, 1927); and the latter from Bermuda (Wheeler, 1940) and Florida (Gibson, 1974).

A cladistic analysis of heteronemerteans by Schwartz and Norenburg (2001), based on internal morphological characters extracted and coded from literature, resulted in a fully unresolved tree, indicating that internal anatomy-at least those characters that have traditionally been mentioned in taxonomic 
descriptions - is uninformative for the purpose of phylogeny inference. When establishing the heteronemertean Pseudomicrura afzelii Strand and Sundberg, 2011, these authors proposed a new standard in nemertean species description. It is based on external features and DNA sequences, without examination of internal anatomy by serial histological sections, a methodology that has been traditionally employed in nemertean systematics (e.g., Gibson, 1985). Strand and Sundberg (2011) advocated that description of internal morphology is not only useless in inferring phylogeny (at least within certain subgroups of the phylum, e.g. Heteronemertea) but also of little help in species identification. In a way, Strand and Sundberg (2011) appear to coincide with a recently-proposed approach called "turbo- taxonomy" (Butcher et al., 2012; Riedel et al., 2013) that aims fast species descriptions combining cyto- chrome c oxidase subunit I (COI) gene sequences, concise morphological descriptions, and high-resolution digital imaging.

In this paper, I describe a new species of branched-proboscis heteronemertean in the genus Gorgonorhynchus, adopting the approach that Strand and Sundberg (2011) put forward, based on its DNA sequences and a concise description of external features accompanied with digital images, which are necessary and sufficient for species identification and systematization. With the DNA sequences obtained, I place the new species in the context of molecular phylogeny using other heteronemertean sequences that are available in the public databases.

\section{Material and Methods}

A single specimen was collected subtidally among coral rubbles at a depth of $6 \mathrm{~m}$ during SCUBA diving in a reef area around Taketomi Island, $24^{\circ} 17.95^{\prime} \mathrm{N}, 124^{\circ} 05.21^{\prime} \mathrm{E}$, on 16 November 2013 by Junko Inoue. It was photographed alive, anaesthetized by dropwise addition of $35 \mathrm{psu} \mathrm{MgCl}_{2}$ solution; its posterior tip was cut off and preserved in $99 \% \mathrm{EtOH}$, while the rest was placed in $10 \%$ formalin-seawater; these processes were executed by Shinri Tomioka. The type material has been deposited in the Hokkaido University Museum, Sapporo, Japan (catalogued under the acronym ZIHU).

Total DNA was extracted using the DNeasy Blood \& Tissue Kit (Qiagen, USA) from the tissue fragment. PCR amplification of the nuclear 18S and 28S rRNA genes, as well as the mitochondrial COI gene were performed with the following primer pairs: for 18S, 1F / 9R (Giribet et al., 1996); for 28S, LSU5 (Littlewood, 1994) / 3KR (Yamasaki et al., 2013); and for COI, LCO1490 / HCO2198 (Folmer et al., 1994). Thermal cycling condition was $95^{\circ} \mathrm{C}$ for $1 \mathrm{~min}, 35$ cycles of $95^{\circ} \mathrm{C}$ for $30 \mathrm{sec}, 45^{\circ} \mathrm{C}$ for $90 \mathrm{sec}$, and $72^{\circ} \mathrm{C}$ for $3 \mathrm{~min}(90$ sec for COI), then $72^{\circ} \mathrm{C}$ for $7 \mathrm{~min}$. Sequences were determined using the BigDye Terminator Kit ver. 3.1 (Life Technologies Co., USA) and a 3730 DNA analyzer (Life Technologies Co., USA), using, in addition to the same primer pairs used for PCR amplification, the following internal primers: for $18 \mathrm{~S}, 2 \mathrm{~F}, 4 \mathrm{~F}, 6 \mathrm{R}$, and $8 \mathrm{R}$ (Giribet et al., 1996); and for 28S, Sa (Whiting et al., 1997), rd4b (Edgecombe and Giribet, 2006), rd4.8a (Schwendinger and Giribet, 2005), rd5b (Schwendinger and Giribet, 2005), F2012 (Giribet et al., 2010), and rd7b1 (Schwendinger and Giribet, 2005). Base calling and assembling were performed with ATGC ver. 4.0.6 (Genetyx).

To assess the phylogenetic affinities of the new species, a preliminary analysis was carried out with 20 species of heteronemerteans, for which COI, $18 \mathrm{~S}$, and $28 \mathrm{~S}$ sequences were available in the public databases (Table 1). Outgroups were chosen to include Baseodiscus mexicanus (Bürger, 1893) and B. unicolor (Stiasny-Wijnhoff, 1925), since Baseodiscus has been shown to be sister to 'Schizonemertini' (i.e., heteronemerteans with lateral cephalic slits) in recent molecular phylogenetic analyses (cf. Andrade et al., 2012; Kvist et al., 2014). Sequence alignment was carried out gene by gene with MUSCLE (Edgar, 2004a, b) implemented in MEGA ver. 5.2.1 (Tamura et al., 2011), then concatenated in Kakusan4 ver. 4.0 (Tanabe, 2011); no significant nucleotide compositional heterogeneity was detected for the combined data $\operatorname{set}(\mathrm{p}=$ 1.00000 by chi-square test in Kakusan4). After eliminating gap positions, the dataset comprised $531 \mathrm{nt}$ (COI), 
$1623 \mathrm{nt}(18 \mathrm{~S})$, and $1805 \mathrm{nt}$ (28S). A shot-gun maximum-likelihood (ML) analysis was performed with RAxML ver. 8.0.0 (Stamatakis, 2014) under general time-reversible model (Tavaré, 1986) considering discrete gamma distribution for among-site rate variation, based on parameters optimized by Kakusan4 with four categories of gamma rate, starting with a tree generated by neighbour-joining method (Saitou and Nei, 1987) using Jukes and Cantor's (1969) distance. The shot-gun search was executed with 10 inferences on the original alignment using 10 distinct randomized maximum-parsimony tree. Bootstrap support values were calculated using 1000 pseudoreplicates.

Table 1. Taxa included in the phylogenetic analysis, with accession numbers in the public databases.

\begin{tabular}{|c|c|c|c|}
\hline \multirow{2}{*}{ Taxa } & \multicolumn{3}{|c|}{ Markers } \\
\hline & $18 \mathrm{~S}$ & $28 \mathrm{~S}$ & COI \\
\hline \multicolumn{4}{|l|}{ Ingroup (Lineidae) } \\
\hline Cerebratulus lacteus (Leidy, 1851) & JF293044 ${ }^{\mathrm{a}}$ & HQ856857 & KC698905 \\
\hline Cerebratulus leucopsis (Coe, 1901) & KF935300 c & KF935356 ${ }^{\mathrm{c}}$ & KF935517 \\
\hline Gorgonorhynchus albocinctus sp. nov. & LC010650 ${ }^{\mathrm{d}}$ & $\mathrm{LC} 010651^{\mathrm{d}}$ & LC010649 \\
\hline Lineus acutifrons Southern, 1913 & $\mathrm{JF} 304778^{\mathrm{a}}$ & HQ856855 ${ }^{\mathrm{a}}$ & GU590937 \\
\hline Lineus bilineatus (Renier, 1804) & $\mathrm{JF} 293041^{\mathrm{a}}$ & HQ856844 ${ }^{\mathrm{a}}$ & GU392015 \\
\hline Lineus torquatus Coe, 1901 & $\mathrm{JF} 293035^{\mathrm{a}}$ & HQ856856 ${ }^{\mathrm{a}}$ & $\mathrm{EF} 124972^{\mathrm{g}}$ \\
\hline Lineus viridis (Müller, 1774) & $\mathrm{JF} 293032^{\mathrm{a}}$ & HQ856854 ${ }^{\mathrm{a}}$ & $\mathrm{KC} 812597^{\mathrm{h}}$ \\
\hline Micrura chlorapardalis Schwartz and Norenburg, 2005 & KF935292 ${ }^{\mathrm{c}}$ & KF935348 ${ }^{\mathrm{c}}$ & KF935512 \\
\hline Micrura fasciolata Ehrenberg, 1828 & JF293039 & HQ856847 ${ }^{\mathrm{a}}$ & GU392022 \\
\hline Micrura ignea Schwartz and Norenburg, 2005 & $\mathrm{JF} 293043^{\mathrm{a}}$ & KF935342 ${ }^{\mathrm{c}}$ & KF935507 \\
\hline Micrura purpurea (Dalyell, 1853) & $J F 293036^{a}$ & HQ856845 ${ }^{\mathrm{a}}$ & HQ848586 \\
\hline Micrura verrilli Coe, 1901 & KF935288 ${ }^{\mathrm{c}}$ & KF935344 ${ }^{\mathrm{c}}$ & KF935508 \\
\hline Notospermus geniculatus (Delle Chiaje, 1828) & KF935295 ${ }^{\mathrm{c}}$ & KF935351 ${ }^{\mathrm{c}}$ & EF $125002^{\mathrm{g}}$ \\
\hline Notospermus sp. 1 & KF935296 ${ }^{\mathrm{c}}$ & KF935352 ${ }^{\mathrm{c}}$ & KF935515 \\
\hline Notospermus sp. 2 & KF935298 ${ }^{\mathrm{c}}$ & KF935354 ${ }^{\mathrm{c}}$ & KF935516 \\
\hline Parborlasia corrugata (McIntosh, 1876) & $\mathrm{JF} 293037^{\mathrm{a}}$ & HQ856851 ${ }^{\mathrm{a}}$ & KC812593 \\
\hline Ramphogordius lacteus Rathke, 1843 & $\mathrm{JF} 293065^{\mathrm{a}}$ & KF935358 ${ }^{\mathrm{c}}$ & KF935519 \\
\hline Ramphogordius sanguineus (Rathke, 1799) & JF293040 & HQ856853 ${ }^{\mathrm{a}}$ & AJ436938 \\
\hline Riseriellus occultus Rogers et al., 1993 & $\mathrm{JF} 293033^{\mathrm{a}}$ & HQ856849 ${ }^{\mathrm{a}}$ & DQ911397 \\
\hline \multicolumn{4}{|l|}{ Outgroup (Valenciniidae) } \\
\hline Baseodiscus mexicanus (Bürger, 1893) & KF935281 ${ }^{\mathrm{c}}$ & KF935337 & KF935503 ${ }^{\mathrm{c}}$ \\
\hline Baseodiscus unicolor (Stiasny-Wijnhoff, 1925) & KF935285 & KF935341 ${ }^{\mathrm{c}}$ & KF935505 \\
\hline
\end{tabular}

Sources: ${ }^{a}$ Andrade et al. (2012); ${ }^{b}$ Lu et al. (unpubl.); ${ }^{\circ} \mathrm{Kvist}$ et al. (2014); ${ }^{\mathrm{d}}$ present study; ${ }^{\mathrm{e}}$ Puerta et al. (2010); ${ }^{\mathrm{f}}$ Strand and Sundberg (2011); ${ }^{\mathrm{g}} \mathrm{S}$ Shwartz and Norenburg (unpubl.); ${ }^{\mathrm{h}}$ Strand et al. (2014); ${ }^{\mathrm{i}}$ Thollesson and Norenburg (2003); ${ }^{\mathrm{j}}$ Sundberg and Strand (2007). 


\section{NEW GORGONORHYNCHUS}

\section{Results and Discussion}

\section{Taxonomy}

Gorgonorhynchus albocinctus sp. nov.

(Figs. 1-2)

http://zoobank.org/:pub:99CB19F0-392A-42EF-91E9-8B852903068B

Material examined. ZIHU 4976, anterior fragment of body and detached proboscis, preserved in 10\% formalin-seawater.

Sequences. Newly determined sequences from the holotype have been deposited in DDBJ with the following accession numbers: LC010649, COI (658 nt); LC010650, 18S rRNA (1792 nt); and LC010651, 28S rRNA (2096 nt).

Description. Holotype lacking tail when collected (Fig. 1A); presence / absence of caudal cirrus unknown. Anterior fragment of body $6 \mathrm{~cm}$ in length, up to $6 \mathrm{~mm}$ in width. In life, dorsally brown, ventrally paler, with white band encircling slightly posterior to tip of head; colour faded and becoming greyish in preserved material, but the white subterminal band still recognizable (Fig. 1B-D). Tip of head darker, almost black in colour (Fig. 1A), obtuse from dorsal view, not rectangular as in Notospermus. Head not demarcated from succeeding portion of body. Horizontal lateral cephalic slits extending back to anterior level of mouth (Fig. 1D). Eyes not found. Anterior portion of body rather rounded cross-sectionally, gradually flattened posteriorly; in intestinal region, lateral margin of body edged as in Cerebratulus.

Proboscis partially everted, detached from body while fixation (Fig. 1E), white in colour. Due to incomplete state of evertion, exact branching pattern difficult to interpret, but appearing to be more or less dichotomous (Fig. 2A), with 32 branches (Fig. 2B).

Remarks. Apparently, the anaesthetization was not sufficiently in effect when the animal was fixed, as the proboscis was everted and detached from the body, but this made the specimen identified as the member of Gorgonorhynchus. The new species differs from the two congeners by the body colour, being brown with a white subterminal band vs. bright reddish-orange in G. repens, light pink or red overall in G. bermudensis; neither of the latter two have any white band (Gibson, 1974). In the Northwest Pacific, three species of lineids have been reported to possess a similar white subterminal band near the tip of the head: Cerebratulus insignis Punnett, 1900 from Singapore, Cerebratulus albocirculus Iwata, 1957 from Sagami Bay, Japan, and Lineus albovittatus (Stimpson, 1855) from Okinawa, Japan.

In C. insignis, the body has an olive-green colour and the tip of the snout is almost black (Punnett, 1900); the latter characteristics is also true to some extent in G. albocinctus (Fig. 1A). The subterminal white band in the preserved specimen of $C$. insignis (Punnett, 1900, pl. 6, fig. 14) is depicted as broad as that of $G$. albocinctus (Fig. 1B-D). According to Punnett (1900), the proboscis was missing in the type material of $C$. insignis; therefore, the possibility cannot be ruled out that the species actually has a branched proboscis, being closely related to G. albocinctus.

Cerebratulus albocirculus was described based on preserved material, and its living state is unknown. Iwata (1957) did not mention any peculiarity about the proboscis in C. albocirculus, thus the proboscis in this species is likely to be a normal, non-branching type, having less phylogenetic affinity to Gorgonorhynchus. 

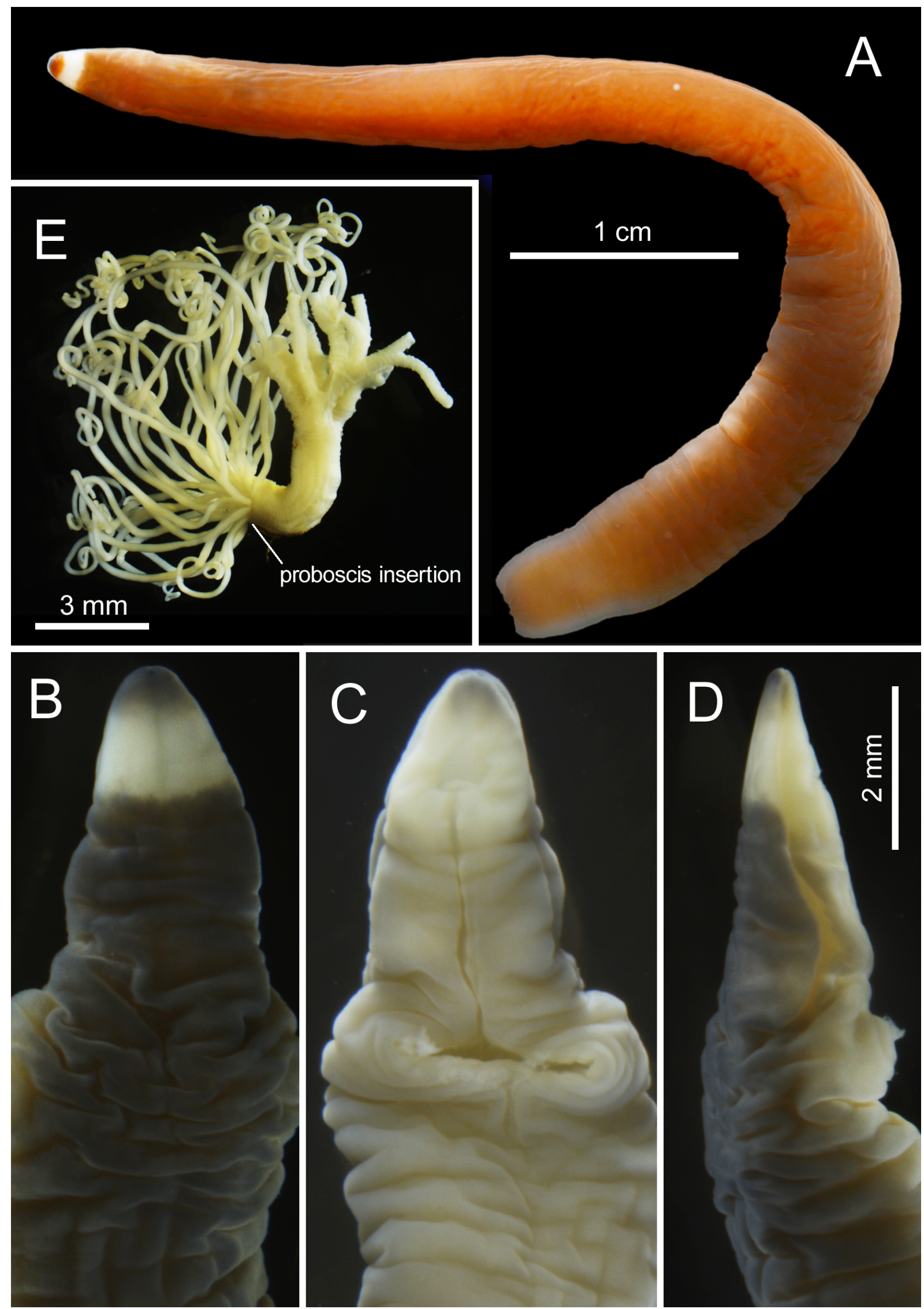

Figure 1. Gorgonorhynchus albocinctus sp. nov., holotype, ZIHU 4976. A, photograph taken in life by Shinri Tomioka; B-E, preserved material. A, anterior fragment, dorsal view; B, head, dorsal view; C, head, ventral view; D, head, right lateral view; E, proboscis, incompletely everted and detached from body. 


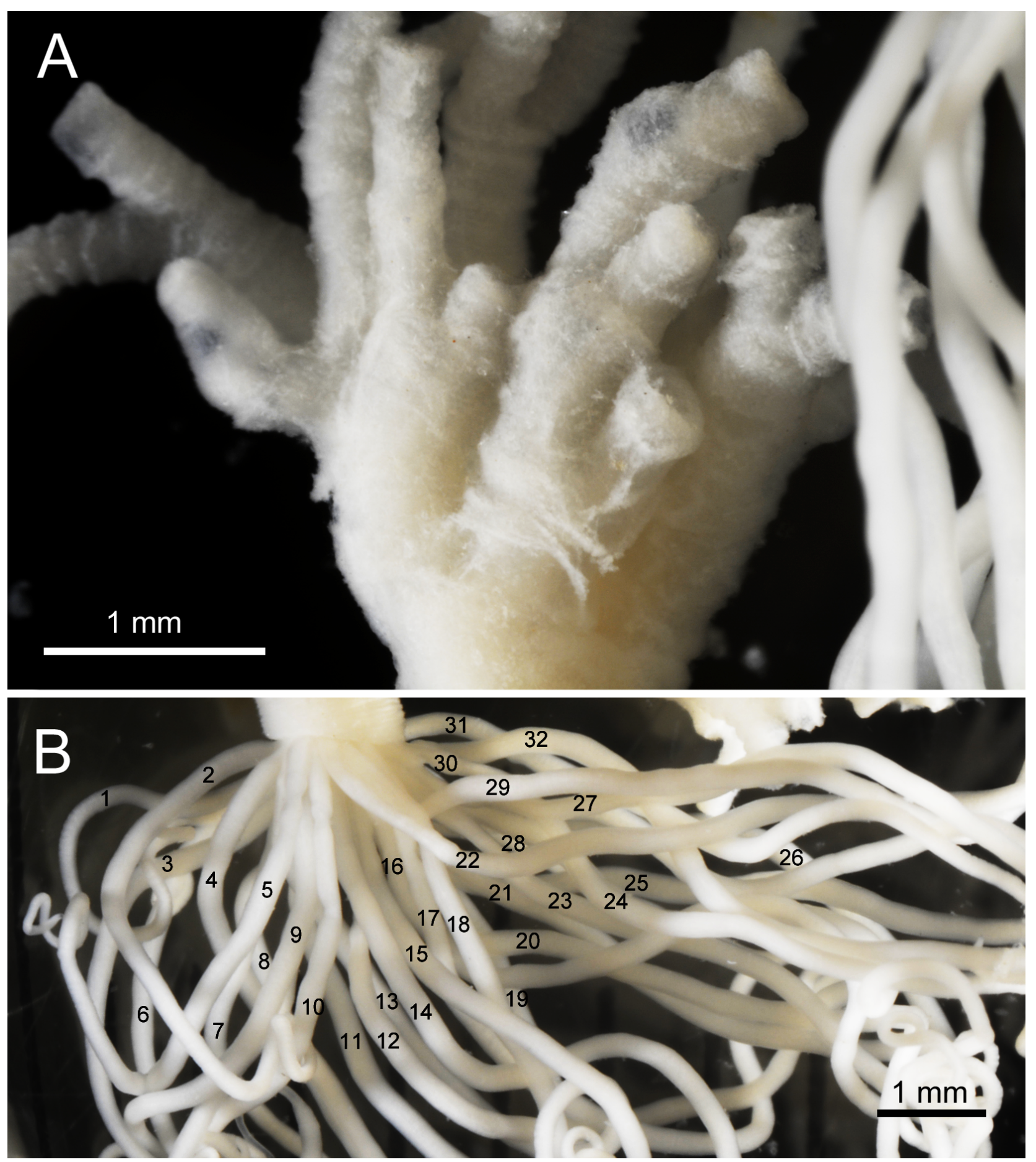

Figure 2. Gorgonorhynchus albocinctus sp. nov., holotype, ZIHU 4976, detached proboscis in preserved state. A, partially everted portion, showing the branching pattern; B, retracted portion, showing 32 branches.

The fixed specimen of C. albocirculus was yellowish green in colour, with the dark green head having a narrow white transverse ring (Iwata, 1957, pl. 1, fig. 7a-c), which appears to agree with Lineus albovittatus that is reported to have a grass-green body with the head "crossed by a white band at a point about the middle of the lateral fissures" (Stimpson, 1855: 382). Altogether, these green forms may closely related to Lineus fuscoviridis Takakura, 1898 that has uniformly green body, and possibly also to Notospermus geniculatus 
(Delle Chiaje, 1828) that shows variably green to brown body with numerous white bands along the body. On the other hand, L. albovittatus sensu Iwata (1954) has white basement body colour with broad, velvet-green longitudinal dorsal stripe, thus appearing to represent a different taxon from L. albovittatus s.str.

A BLAST search (Altschul et al., 1997) at the NCBI website (http://blast.ncbi.nlm.nih.gov) with the COI sequence of G. albocinctus (LC010649) showed that it was 85\% identical with those of Micrura dellechiajei (Kvist et al., 2014) (with 99\% query coverage) and 'Dendrorhynchus sinensis' [the name should be Polydendrorhynchus zhanjiangensis: see Kajihara et al. (2008) for nomenclatural discussion)] (Xu, unpublished, direct submission) (with 93\% query coverage), suggesting a close phylogenetic relation between them.

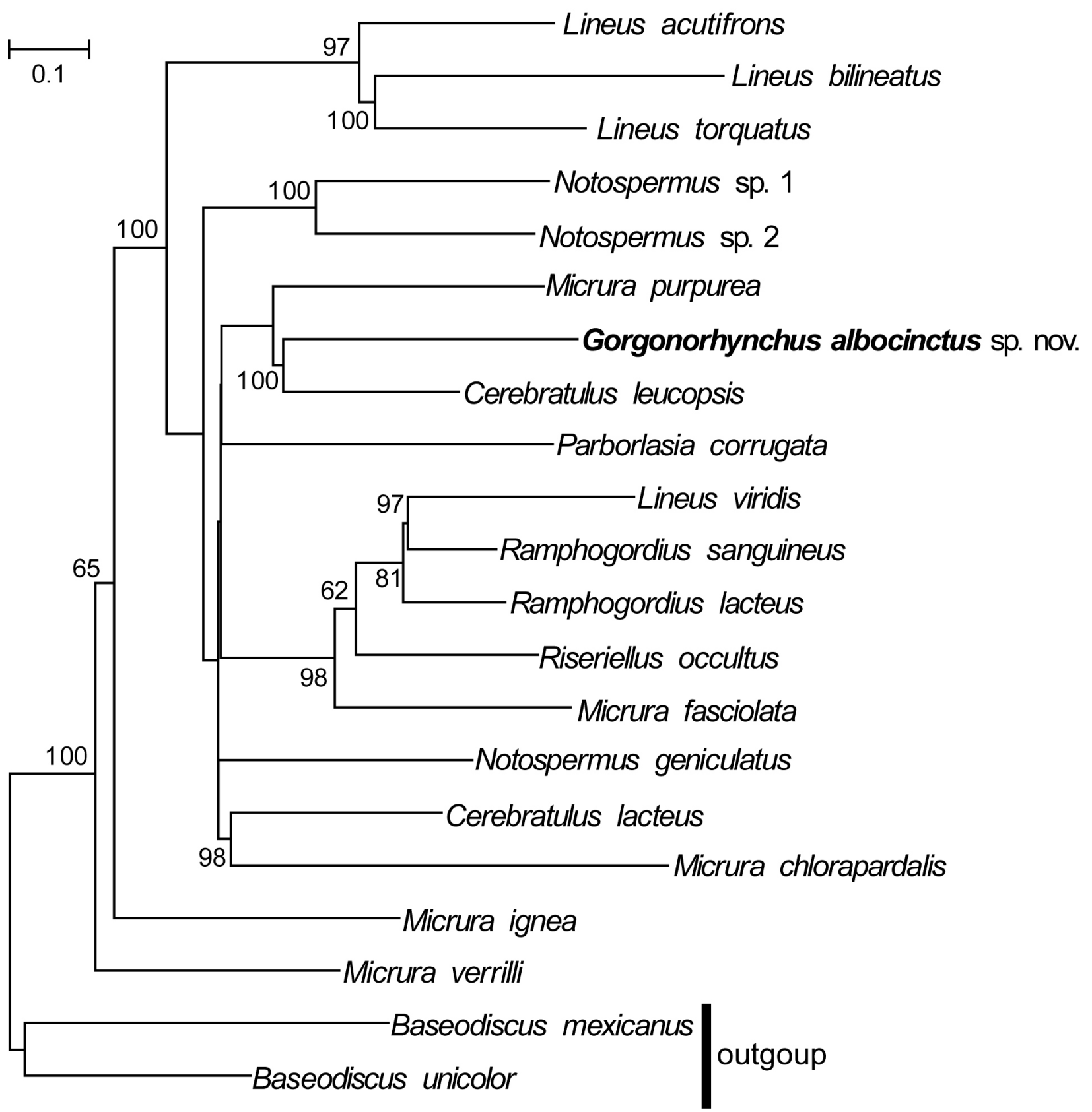

Figure 3. Phylogenetic tree resulting from maximum-likelihood analysis of combined COI, $18 \mathrm{~S}$, and $28 \mathrm{~S}$ rDNA sequences ( $\ln \mathrm{L}=-19143.329006$ ). Numbers near nodes indicate bootstrap support values $\geq 50 \%$. 


\section{Molecular Phylogeny}

In the resulting maximum-likelihood tree ( $\ln \mathrm{L}=-19143.329006)$ (Fig. 3), G. albocinctus was the sister taxon to Cerebratulus leucopsis (Coe, 1901), supported with 100\% bootstrap frequency (BF), although the latter species is supposed to have a non-branched proboscis. The tree topology is thus in favour of Chernyshev's (2011) synonymization of Gorgonorhynchidae with Lineidae. Other well-supported clades recovered in the analysis include: Lineus acutifrons Southern, $1913+$ L. bilineatus (Renier, 1804) $+L$. torquatus Coe, 1901 (97\% BF); Notospermus sp. $1+$ sp. 2 (100\% BF); L. viridis (Müller, 1774) + Ramphogordius sanguineus (Rathke, 1799) + Ra. lacteus Rathke, $1843+$ Riseriellus occultus Rogers et al., $1993+$ Micrura fasciolata (Dalyell, 1853) (98\% BF); and C. lacteus (Leidy, 1851) + M. chlorapardalis Schwartz and Norenburg, 2005 (98\% BF). As has been repeatedly pointed out in previous studies (Sundberg and Saur, 1998; Andrade et al., 2012; Kvist et al., 2014), most of the heteronemertean genera as currently diagnosed are non-monophyletic. Ideally, future analyses including as many type species of genus-group names as possible should be done for proper application of genus names for many species.

\section{Acknowledgments}

I am grateful to Kazumi Okuda and Yoshimichi Akutsu (dive shop Ishigaki Sensui Dou) for their cooperation in the field survey; to Daisuke Uyeno (Kagoshima University) and Hiroshi Yamasaki (University of Ryukyus) for organizing the field survey; to Junko Inoue (University of Tokyo) and Shinri Tomioka (Hokkaido University) for collecting and processing the specimen; to Shushi Abukawa (Hokkaido University) for help in molecular work; to Shimpei Hiruta (Hokkaido University) and Keiichi Kakui (Hokkaido University) for assisting phylogenetic analysis; and to Malin Strand (Swedish University of Agricultural Sciences) and Alexei V. Chernyshev (A.V. Zhirmunsky Institute of Marine Biology) for their valuable comments on the manuscript. This study was financially supported by JSPS KAKENHI Grant Numbers 23370038 (Principal Investigator: Matthew H. Dick) and 2565013 (Principal Investigator: Hiroshi Kajihara).

\section{Literature Cited}

Altschul, S. F., Madden, T. L., Schäffer, A. A., Zhang, J., Zhang, Z., Miller, W. and Lipman, D. J. 1997. Gapped BLAST and PSI-BLAST: a new generation of protein database search programs. Nucleic Acids Research, 25, 3389-3402.

Andrade, S. C. S., Strand, M., Schwartz, M., Chen, H.-X., Kajihara, H., Döhren, J. von, Sun, S.-C., Junoy, J., Thiel, M., Norenburg, J. L., Turbeville, J. M., Giribet, G. and Sundberg, P. 2012. Disentangling ribbon worm relationships: multi-locus analysis supports traditional classification of the phylum Nemertea. Cladistics, 28(2), 141-159.

Bürger, O. 1893. Südgeorgische und andere exotische Nemertinen. Zoologische Jahrbücher, Abteilungen Systematik, Ökologie und Geographie der Tiere, 7, 207-240.

Butcher, B.A., Alex Smith, M., Sharkey, M. J. and Quicke, D. L. J. 2012. A turbo-taxonomic study of Thai Aleiodes (Aleiodes) and Aleiodes (Arcaleiodes) (Hymenoptera: Braconidae: Rogadinae) based largely on COI barcoded specimens, with rapid descriptions of 179 new species. Zootaxa, 3457, 1-232.

Chernyshev, A. V. 2011. Comparative Morphology, Systematics and Phylogeny of the Nemerteans. Dalnauka, Vladivostok, 309 pp. (In Russian)

Coe, W. R. 1901. The nemerteans of Porto Rico. Bulletin of the United States Commission of Fish and Fisheries for 1900, 2, 223-229. 


\section{HIROSHI KAJIHARA}

Coe, W. R. 1947. Nemerteans of the Hawaiian and Marshall Islands. Occasional Papers of Bernice P. Bishop Museum, 19, 101-106.

Dakin, W. J. and Fordham, M. G. C. 1931. A new and peculiar marine nemertean from the Australian coast. Nature, 128, 796.

Dalyell, J. G. 1853. The Powers of the Creator Displayed in the Creation; or, Observations on Life amidst the Various Forms of the Humbler Tribes of Animated Nature: with Practical Comments and Illustrations, Volume II. Van Voorst, London, xiii +359 pp.

Delle Chiaje, S. 1828. Memorie sulla Storia e Notomia degli Animali senza Vertebre del Regno di Napoli, Volume III. Società Tipografica, Naples, xix $+232 \mathrm{pp}$.

Edgar, R. C. 2004a. MUSCLE: multiple sequence alignment with high accuracy and high throughput. Nucleic Acids Research, 32, 1792-1797.

Edgar, R. C. 2004b. MUSCLE: a multiple sequence alignment method with reduced time and space complexity. BMC Bioinformatics, 5, 113.

Edgecombe, G. D. and Giribet, G. 2006. A century later-a total evidence re-evaluation of the phylogeny of scutigeromorph centipedes (Myriapoda: Chilopoda). Invertebrate Systematics, 20, 503-525.

Ehrenberg, C. G. 1828, 1831. Phytozoa turbellaria Africana et Asiatica in Phytozoorum Tabula IV et V delineata. In, Hemprich, F. G. and Ehrenberg, C. G. (eds.) Symbolae Physicae, seu Icones et Descriptiones Corporum Naturalium Novorum aut Minus Cognitorum Quae ex Itineribus par Libyam, Aegyptium, Nubiam, Dongalam, Syriam, Arabiam et Habessiniam, Pars Zoologica II, Animalia Evertebrata Exclusis Insectis. Officina Academica, Berlin, pp. 53-67, pls IV-V (plates published in 1828, text in 1831).

Fernández-Álvarez, F. Á. and Anadón, N. 2012. Oligodendrorhynchus hesperides gen. et sp. n. (Heteronemertea) from the Bellingshausen Sea. Polish Polar Research, 33, 81-98.

Folmer, O., Black, M., Hoeh, W., Lutz, R. and Vrijenhoek, R. C. 1994. DNA primers for amplification of mitochondrial cytochrome c oxidase subunit I from diverse metazoan invertebrates. Molecular Marine Biology and Biotechnology, 3, 294-299.

Gibson, R. 1974. Occurrence of the heteronemertean Gorgonorhynchus bermudensis Wheeler, 1940, in Floridan water. Bulletin of Marine Science 24(3), 473-492.

Gibson, R. 1977. A new genus and species of lineid heteronemertean from South Africa, Polybrachiorhynchus dayi (Nemertea: Anopla), possessing a multi-branched proboscis. Bulletin of Marine Science, 27, 552571.

Gibson, R. 1981. Nemerteans of the Great Barrier Reef 3. Anopla Heteronemertea (Lineidae). Zoological Journal of the Linnean Society, 71, 171-235.

Gibson, R. 1985. The need for a standard approach to taxonomic descriptions of nemerteans. American Zoologist, 25, 5-14

Giribet, G., Carranza, S., Baguña, J., Riutort, M. and Ribera, C. 1996. First molecular evidence for the existence of a Tardigrada + Arthropoda clade. Molecular Biology and Evolution, 13, 76-84.

Giribet, G., Vogt, L., Pérez González, A., Sharma, P. and Kury, A. B. 2010. A multilocus approach to harvestman (Arachnida: Opiliones) phylogeny with emphasis on biogeography and the systematics of Laniatores. Cladistics, 26, 408-437.

Gravely, F. H. 1927. Nemertinea. Bulletin of the Madras Government Museum, New Series, Natural History, $1,53-54$.

Iwata, F. 1957. Nemerteans from Sagami Bay. Publications from the Akkeshi Marine Biological Station, 7, 131.

Jukes, T. H. and Cantor, C. R. 1969. Evolution of protein molecules. In, Munro, H. N. (ed.) Mammalian Protein Metabolism. Academic Press, New York, pp. 21-132.

Kajihara, H., Chernyshev, A. V., Sun, S.-C., Sundberg, P. and Crandall, F. B. 2008. Checklist of nemertean genera and species published between 1995 and 2007. Species Diversity, 13, 245-274. 
Kvist, S., Laumer, C. E., Junoy, J. and Giribet, G. 2014. New insights into the phylogeny, systematics and DNA barcoding of Nemertea. Invertebrate Systematics, 28, 287-308.

Leidy, J. 1851. Helminthological contributions-No. 3. Proceedings of the Academy of Natural Sciences of Philadelphia, 5, 239-244.

Littlewood, D. T. 1994. Molecular phylogenetics of cupped oysters based on partial 28S rRNA gene sequences. Molecular Phylogenetics and Evolution, 3, 221-229.

McIntosh, W. C. 1876. Descriptions of some new species of Annelida from Kerguelen's Island. Annals and Magazine of Natural History, Series 4, 17, 318-323.

Müller, O. F. 1774. Vermivm Terrestrium et Fluviatilium, seu Animalium Infusoriorum, Helminthicorum et Testaceorum, non Marinorum, Succincta Historia, Voluminis Primi Pars Altera. Heineck \& Faber, Kopenhagen \& Leipzig, 72 pp.

Puerta, P., Andrade, S. C. S. and Junoy, J. 2010. Redescription of Lineus acutifrons Southern, 1913 (Nemertea: Pilidiophora) and comments on its phylogenetic position. Journal of Natural History, 44(3740), 2363-2378.

Punnett, R. C. 1900. On a collection of nemerteans from Singapore. Quarterly Journal of Microscopical Science, 44, 111-139.

Rathke, H. 1843. Beiträge zur Fauna Norwegens. Verhandlungen der Kaiserlichen LeopoldinischCarolinischen Akademie der Naturforscher, 20, 1-264.

Rathke, J. 1799. Jagttagelser henhörende til Indvoldeormenes og Blöddyrenes Naturhistorie. Skrivter af Naturhistorie Selskabet, 5, 61-148.

Renier, S. A. 1804. Prospetto della Classe dei Vermi. Author's personal publication, pp. xv-xxvii.

Riedel, A., Sagata, K., Suhardjono, Y. R., Tänzler, R. and Balke, M. 2013. Integrative taxonomy on the fast track-towards more sustainability in biodiversity research. Frontiers in Zoology, 10, 15.

Rogers, A. D., Junoy, J., Gibson, R. and Thorpe, J. P. 1993. Enzyme electrophoresis, genetic identity and description of a new genus and species of heteronemertean (Nemertea, Anopla) from northwestern Spain and North Wales. Hydrobiologia, 266, 219-238.

Saitou, N. and Nei, M. 1987. The neighbor-joining method: a new method for reconstructing phylogenetic trees. Molecular Biology and Evolution, 4(4), 406-425.

Schwartz, M. L. and Norenburg, J. L. 2001. Can we infer heteronemertean phylogeny from available morphological data? Hydrobiologia, 456, 165-174.

Schwartz, M. L. and Norenburg, J. L. 2005. Three new species of Micrura (Nemertea: Heteronemertea) and a new type of heteronemertean larva from the Caribbean Sea. Caribbean Journal of Science, 41(3), 528543.

Schwendinger, P. J. and Giribet, G. 2005. The systematics of the southeast Asian genus Fangensis Rambla (Opiliones: Cyphophthalmi: Stylocellidae). Invertebrate Systematics, 19, 297-323.

Serna de Esteban, C. J. de la and Moretto, H. J. A. 1969. Un nuevo heteronemertino con proboscis ramificada Panorhynchus argentinensis gen. et sp. nov. Ciencia e lnvestigación, 25, 166-171.

Southern, R. 1913. Nernertinea. Proceedings of the Royal Irish Academy, 31, 1-20.

Stamatakis, A. 2014. RAxML version 8: a tool for phylogenetic analysis and post-analysis of large phylogenies. Bioinformatics, 30, 1312-1313.

Stiasny-Wijnhoff, G. 1925. On a collection of nemerteans from Curaçao. Bijdragen tot de Dierkunde, 24, 97120.

Stimpson, W. 1855. Descriptions of some of the new marine Invertebrata from the Chinese and Japanese seas. Proceedings of the Academy of Natural Sciences of Philadelphia, 7, 375-384.

Strand, M., Herrera-Bachiller, A., Nygren, A. and Kånneby, T. 2014. A new nemertean species: what are the useful characters for ribbon worm descriptions? Journal of the Marine Biological Association of the United Kingdom, 94(2), 317-330. 


\section{HIROSHI KAJIHARA}

Strand, M. and Sundberg, P. 2011. A DNA-based description of a new nemertean (phylum Nemertea) species. Marine Biology Research, 7, 63-70.

Sun, S.-C. 2006. On nemerteans with a branched proboscis from Zhanjiang, China. Journal of Natural History, 40, 943-965.

Sundberg, P. and Saur, M. 1998. Molecular phylogeny of some European heteronemertean (Nemertea) species and the monophyletic status of Riseriellus, Lineus, and Micrura. Molecular Phylogenetics and Evolution, $10,271-280$.

Sundberg, P. and Strand, M. 2007. Genetics do not reflect habitat differences in Riseriellus occultus (Heteronemertea, Nemertea) from Spain and Wales. Marine Biology Research, 3(2), 117-122.

Takakura, U. 1898. Misaki kinbou san himomushirui (Nemerine) no bunrui [Classification of ribbonworms (Nemertea) from the vicinity of Misaki]. Zoological Magazine, Tokyo, 10, 38-44, 116-120, 184-187, 331-337, 424-429. [In Japanese]

Tamura, K., Peterson, D., Peterson, N., Stecher, G., Nei, M. and Kumar, S. 2011. MEGA5: molecular evolutionary genetics analysis using maximum likelihood, evolutionary distance, and maximum parsimony methods. Molecular Biology and Evolution, 28, 2731-2739.

Tanabe, A. S. 2011. Kakusan4 and Aminosan: two programs for comparing nonpartitioned, proportional and separate models for combined molecular phylogenetic analyses of multilocus sequence data. Molecular Ecology Resources, 11, 914-921.

Tavaré, S. 1986. Some probabilistic and statistical problems in the analysis of DNA sequences. In, Miura, E. M. (ed.) Some Mathematical Questions in Biology_DNA Sequence Analysis. American Mathematical Society, Providence, Rhode Island, pp. 57-86.

Thollesson, M. and Norenburg, J. L. 2003. Ribbon worm relationships: a phylogeny of the phylum Nemertea. Proceedings of the Royal Society B, 270, 407-415.

Wheeler, J. F. G. 1940. Notes on Bermudan nemerteans: Gorgonorhynchus bermudensis, sp. n. Annals and Magazine of Natural History, Series 11, 6, 433-438.

Whiting, M. F., Carpenter, J. M., Wheeler, Q. D. and Wheeler, W. C. 1997. The Strepsiptera problem: phylogeny of the holometabolous insect orders inferred from $18 \mathrm{~S}$ and $28 \mathrm{~S}$ ribosomal DNA sequences and morphology. Systematic Biology, 46, 1-68.

Yamasaki, H., Hiruta, S. F. and Kajihara, H. 2013. Molecular phylogeny of kinorhynchs. Molecular Phylogenetics and Evolution, 67, 303-310.

Yin, Z. and Zeng, F. 1984, The study of a new species of genus Dendrorhynchus-Dendrorhynchus zhanjiangensis, of lineid heteronemertean, possessing multibranched proboscis. Marine Science Bulletin, $3,51-58$.

Received: 7 Apr 2015

Accepted: 15 May 2015

Published: 15 Sept 2015 